Revista Internacional de Apoyo a la Inclusión, Logopedia, Sociedad y Multiculturalidad.

Volumen 7, Número 1, enero 2021, ISSN: 2387-0907. DOI: https://dx.doi.org/10.17561/riai.v7.n1.8

\title{
Critical review: From neglect to a new look: the construction of the National Policy of Integral Attention to Users of Alcohol and Other Drugs as a conquest of the Brazilian Psychiatric Reform. The case of Recife (PE)
}

Resenha crítica: Do descaso a um novo olhar: a construção da Política Nacional de Atenção Integral aos Usuários de Álcool e Outras Drogas como conquista da Reforma Psiquiátrica Brasileira. $O$ caso de Recife (PE)

\begin{abstract}
Revisión crítica: De la negligencia a una nueva mirada: la construcción de la Política Nacional de Atención Integral al Usuario de Alcohol y Otras Drogas como conquista de la Reforma Psiquiátrica Brasileña. El caso de Recife (PE) Kritischer Rückblick: Von der Vernachlässigung zu einem neuen Erscheinungsbild: der Aufbau der Nationalen Politik der integralen Betreuung von Konsumenten von Alkohol und anderen Drogen als Eroberung der brasilianischen Psychiatriereform. Der Fall Recife (PE)

Revue critique : De la négligence à un nouveau regard : la construction de la Politique nationale de soins intégrés pour les consommateurs d'alcool et d'autres drogues comme une conquête de la réforme psychiatrique brésilienne. Le cas de Recife (PE)

Revisione critica: dall'incuria a un nuovo look: la costruzione della Politica Nazionale di Assistenza Integrale per i consumatori di alcol e altre droghe come conquista della Riforma Psichiatrica Brasiliana. II caso di Recife (PE)

Критический обзор: От пренебрежения к новому взгляду: построение национальной политики комплексного ухода за потребителями алкоголя и других наркотиков как завоевание бразильской реформы психиатрии. Дело Ресифи (РЕ)

批判的レビュー: ネグレクトから新たな眼差しへ：ブラジル精神医学改革の征服としてのアルコール等薬物使用者 に対する統合的ケアの国策の構築 レシフェ (PE) の場合

批判性评论 : 从忽视到新的面貌：构建 "酒精和其他药物使用者综合护理国家政策 "是对巴西精神病学改革的征服。累 西腓案例 $(P E)$

Stefany De Barros Camargo Pontificia Universidade Católica de Goiás (Brasil) stefanydebarroscamargo@gmail.com
\end{abstract}

Fecha recepción: 05/09/2020

Páginas 114-118

Fecha aceptación: 29/12/2020

\begin{abstract}
.
This work is based on secondary sources such as the conquest of the Brazilian Psychiatric Reform. It is an exploratory study, with the objective of briefly examining the structuring and transformations of mental health policies in Brazil. On the other hand, it seeks to highlight fragments in the enunciation mechanisms that strengthen services aimed at caring for people in psychic suffering. In conclusion, the analysis shows that, in some people, society shows different behavior patterns and norms, and they react differently to the problem in question. And that mental illness is now considered a social degeneration. And in this sense, we emphasize the necessary care to the carriers of this disease, as well as the importance of a quality nursing care. And this aspect, is emphasized in some congresses and seminars held for a social education, mainly in the aspect of education and awareness of drug use. And reinforced the construction of the National Policy of Integral Attention to Users of Alcohol and Other Drugs as a conquest of the Brazilian Psychiatric Reform. The case of Recife (PE).
\end{abstract}

Keywords: social education; mental illness; drugs; social reform 


\section{Resumo.}

Este trabalho, está fundamentado em fontes secundárias como a conquista da Reforma Psiquiátrica Brasileira. É um estudo de caráter exploratório, tendo como objetivo examinar, de forma sucinta, a estruturação e transformações das políticas de saúde mental no Brasil. Por outra parte, busca destacar fragmentos nos mecanismos de enunciação que fortalecem os serviços voltados ao cuidado das pessoas em sofrimento psíquico. Em conclusão a análise nos mostra que, a sociedade demostra em algumas pessoas diferentes padrões e normas de comportamento, capa pessoa reage de forma diferente frente ao problema em questão. $E$ que a doença mental passou a ser considerada uma degeneração social. E neste sentido, destacamos os cuidados necessários aos portadores desta enfermidade, como também a importância de um atendimento de enfermagem de qualidade. E este aspecto, está enfatizado em alguns congressos e seminários realizados em para uma educação social, principalmente no aspecto de educação e conscientização do uso de drogas. $E$ reforçado a construção da Política Nacional de Atenção Integral aos Usuários de Álcool e Outras Drogas como conquista da Reforma Psiquiátrica Brasileira. O caso de Recife (PE).

Palavras chaves: educação social, doença mental, drogas, reforma social

\section{1.-Introduction.}

This article refers to an extensive bibliographic review of an article entitled: From neglect to a new look: the construction of the National Policy of Integral Attention to Users of Alcohol and Other Drugs as a conquest of the Brazilian Psychiatric Reform. The case of Recife (PE).

\section{2.-Review.}

The research showed that among the models of services aimed at caring for people in psychic distress, and much more recently, people with problems resulting from the use/abuse of alcohol and other drugs, we highlight the relevance of some that, for now, may be composing the so-called Psychosocial Attention Networks (RAPS). Another aspect that the article highlights is that a good part of these models work with the goal of achieving "abstinence", seen as a condition for possible "cure". On the other hand, the article continues to refer to the new parameters of attention aimed at minimizing the possible harm arising from drug use, but without bringing in its operative body the "moralistic conception" of the abrupt interruption of the use/abuse of psychoactive drugs (Mota, 2008; Rameh-de-Albuquerque, 2008; Lira, 2016), as is the case of Harm Reduction, which proposes that services in $A D$ need to formulate therapeutic strategies anchored in the reality of each actor, taking into account other goals beyond the attainment of abstemia (Santos et. al, 2010).

In the article Goffman (1974), he states that society demonstrates in some people a lack of norms and standards of behavior, however, these being segregated from the "civilizing process". So that in this social process the relationships between individuals 
may or may not be transformed into a lasting relationship with its own characteristics (GOFFMAN, 1974, p. 42).

In an appeal for information to understand the subject dealt with in the article, the author comments that from 1830 onwards, in the Portuguese colonial empire they created a hospice. And around 1841 the first Brazilian psychiatric hospital was founded - in Rio de Janeiro - called "Hospice D. Pedro II", being the first specialized in mental diseases. At the beginning of the 19th century, madness was studied as an object of intervention. And being in this period of modernization and consolidation of the Brazilian nation that the country has been seen as independent, especially when the socioeconomic situation presents unfavorable characteristics so that some institutions can develop a service with conditions of hygiene and adequate care.

Around 1930, in the article it is highlighted that mental illness started to be considered a "moral degeneration" and therefore, it was the determined laws, so that with these, a change was possible. In other words, a transformation in the sense of improving the position worldwide, including a look at the need for psychiatric assistance, which has historically been forgotten and denied to those considered mentally invalid, as Delgado (2005) states in the article. (RAMEH-DE-ALBUQUERQUE et. al, 2017 p. 02).

Therefore, international experiences were the greatest inspiration for the Brazilian Psychiatric Reform. A social and political transformation has begun. And soon, followed by an intervention in the process of building spaces for the coexistence of society.

The article in question highlights the main concepts related to mental health policies that we can consider here as a political-legal agreement that is established in a given society on the conception of and answers to problems of mental madness or disease. Another important point referring to the movements and transfigurations on the care of the mentally ill, where the article emphasizes the social movement entitled "Brazilian Psychiatric Reform" (RPB) started in face of organizational, political, structural, economic and cultural commutations, thus becoming essential the trace of judicious solutions, in face of the search for an effective public policy of mental health care.

In Brazil, in a peculiar historical context full of conflicts inherent to the military dictatorship period, initiatives and affluences became in force, evidencing the debates on citizenship, social inclusion and validation of Human Rights. Objective and necessary reforms in which the authors of this article address the institutional articulations started in 1986.

And in this sense, the article reflects that the new models of therapies, among the poorly used, stand out those used with people with problems arising from the use of alcohol and other drugs. Where these deserve relevance of the so-called Psychosocial Attention Networks (RAPS). And that institutions need to be guided by the perspective of harm reduction, so that people have guaranteed and humanized care. It becomes the necessary operationalization and seen as another therapeutic model in Brazil, since the Ministry of Health, through the Secretariat of Health Care, published the "Ordinance 
No. 1. 482, DOU 27" of October 2016, including in the "Table of Types of Health Establishments of the National Health Establishments Cadastre" (CNES), it imposes, for the most part, an "obligation" - the scope of abstinence and religious conversion to people who use/used drugs and treated themselves in those spaces (RAMEH-DEALBUQUERQUE et. al, 2017 p. 02).

In Recife, where the study is carried out, the article states that in 2000 the "Itinerant Seminar on Drugs and Risk Behavior" was held with the presence of local and world specialists in RD. This event, aimed at important scientific debates, and began the creation of the Pernambuco Network of Harm Reduction, being one of the 05 first states" of Brazil (Brazil, 2004). Something that marked the beginning of great changes, events that seek to reduce the rates of homicides and violence that stood out in the State of Pernambuco. And currently the scenario of disinvestment in financing SUS and SUAS25 policies and programs at the national level also echoes in the local scenario.

The article highlights that the experiences of Recife, through the extinct Mais Vida Program, in Pernambuco, emphasizes the struggle to change attitudes in meeting a demand that was visible, especially people who use crack in street situations, who needed existing services, or who were in a situation of vulnerability resulting from social exclusion.

The article in question reinforces that both the experiences of Recife, and that of the State Government, allow us to understand the operations from a Harm Reduction perspective. Analyzing the concepts of the article allows us to think that the main objective is to promote citizenship and strengthen the participation of people in need of special care, guaranteeing their autonomy, eliminating barriers and allowing access and enjoyment, on an equal basis, of the goods and services available to today's society.

Finally, it is important to emphasize that the article, we understand the striking aspect in the history of social change with the developed legislation. And that, in a way, it allows us to rethink our attitudes and also to question the actions of our rulers. In a certain way, the reading of the aforementioned article allows us to broaden the scope generally achieved by other perspectives and models of care, configuring in fact an achievement of the Brazilian Psychiatric Reform.

This change introduces the criterion of equality to guarantee the necessary and indispensable treatment to those who need it, especially those who use drugs and need treatment based on the subject's uniqueness and social well-being. 


\section{3.-References.}

Basaglia, F. (2001). A instituição negada: relato de um hospital psiquiátrico. Rio de Janeiro: Graal.

Birman, J. (1992). A cidadania tresloucada. In: Bezerra, B. \& Amarante, P. (Ed.), Psiquiatria sem hospício: contribuições ao estudo da reforma psiquiátrica ( $p .71$ 90). Rio de Janeiro: Relume-Dumará.

Goffman, E. (1974). Manicômios, prisões e conventos. São Paulo: Perspectiva.

Lira, W.L. (2016). Daqui nós tira um ouro de chá! Umbanda, Santo Daime e xamanismo popular no tratamento religioso de patologias físicas, mentais e espirituais. 0 caso de um Terreiro alagoano. Tese (Doutorado) em Antropologia (485p). Recife: UFPE.

MS (2004). Portaria N².197, de 14 de outubro de 2004. Ministério da Saúde: Brasília. Acesso em: 10 de setembro de 2020, em http://bvsms.saude.gov.br/bvs/saudelegis/gm/2004/prt2197_14_10_2004.htm. https://doi.org/10.1590/S0103-73312004000200003

Rameh de Albuquerque, R.C. (2008). Casas do Meio do Caminho: um relato da experiência de Recife na busca da atenção integral à saúde dos usuários de álcool, fumo e outras drogas. Dissertação (Mestrado) em Saúde Pública (223p). Recife: Centro de Pesquisa Aggeu Magalhães: Fundação Oswaldo Cruz. https://doi.org/10.24879/2017001100100215

Rameh De Albuquerque, R.C. et al (2017). Do descaso a um novo olhar: a construção da Política Nacional de Atenção Integral aos Usuários de Álcool e Outras Drogas como conquista da Reforma Psiquiátrica Brasileira. O caso de Recife (PE). Psicol. pesq., Juiz de Fora, v. 11, n. 1, p. 1-2, jun. 2017. Disponível em <http://pepsic.bvsalud.org/scielo. Acesso em: 23 de set. http://dx.doi.org/10.24879/2017001100100215.

Santos, V.E., Baldini, Cássia, S., Campos, C.M.S. (2010). Redução de danos: análise das concepções que orientam as práticas no Brasil. Physis - Revista de Saúde Coletiva, 3, 20, 995-1015. https://doi.org/10.1590/S0103-73312010000300016 